\title{
A Balanced Viewpoint in the Early Management of Patients with Spinal Injuries who have Neurological Damage $^{\star}$
}

\author{
G. M. Bedbrook, Kt., O.B.E., O.St.J., M.S. (Melb.), Hon. M.D. (W.A.)., \\ Hon. F.R.C.S. (Edin.)., F.R.C.S., F.R.A.C.S., D.P.R.M. (Syd.) \\ Royal Perth (Rehabilitation) Hospital, Selby Street, Shenton Park, Western \\ Australia 6008
}

Mr President of this Conference, Mr President of the French Speaking Society for Paraplegia, and colleagues in the care of those with spinal paralysis, despite much research and investigation, fractures and fracture-dislocations of the spine associated with neurological damage are regretfully amongst the great galaxy of surgical conditions for which we, as medical scientists, have as yet no really curative treatment. Like the great European surgeons of the past (of this century and the last), we must thus serve the practice of Medicine in the restoration of function, for real replacement therapy is not yet possible. Fortunately for man, a growing number of clinico-pathological states, such as infections, hormone diseases, blood dyscrasias, vitamin deficiency disorders, and new organ transplants have, of course, given us as medical scientists curable conditions.

Those of us involved in the traumatic states of the human spine, whether we be neurosurgeons, general surgeons, orthopaedic surgeons, or rehabilitation specialists, have few replacement therapies except occasionally for homologous bone grafting. Therefore we must rely on the restoration of function by the use of tissue and organ reserves. These reserves are great indeed. It has been justly said that one only needs to have a small amount of a tissue to have normal function. Throughout the last two centuries European surgeons have emphasised the importance of such tissue reserves. Sir Arthur Keith's famous monograph 'Menders of the Maimed' (1919) lists those surgeons whose then aggressive but controversial (but in our eyes conservative), methods as used in the late nineteenth century led ultimately to better restorative programmes.

The controversy about management of such fracture-dislocations began over 150 years ago with the argument between the famous Cooper and Bell. The real issue, however, is what constitutes surgical method. Far too much debate, in my opinion, has centred on one method, that of open reduction. Sir Arthur Keith, in his 'Menders of the Mained' published in 1919, discussed those methods which we now call conservative, as well as the emergent technical procedures. Such

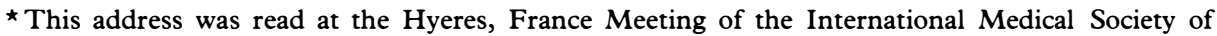
Paraplegia, January 1984.
} 
so-called conservative methods as posture, muscle re-education, and exoskeletons, were the dominant surgical methods of the last century but must still be regarded as medically aggressive activities. The discovery of techniques of internal fixation has doubled the risk rates as far as complications are concerned, for complications have skyrocketed, even by as much as 50 per cent in some series. Leach, Hoaglund and Riseborough's recent publication on such controversies discusses these methods in depth. As we discuss the use of management methods we must be guided principally by the academic principles as well as by the patho-physiological condition of each patient encountered, for each is an individual and each is different. It is also important to be certain where the patient will be treated and by whom the patient is to be treated. All of these factors affect the surgical decision. Surgical judgement or surgical balance is of much greater importance than surgical technique.

The advantages or disadvantages of any particular method of acute management of spinal injuries must be considered before a particular programme of management is laid down to suit the individual, as well as that individual's fractures. There are a number of academic facts of importance to be properly assessed before each individual patient can be treated.

\section{Pathology}

It must be remembered that 90 per cent of fractures of the spine will heal spontaneously after adequate, but not necessarily perfect reduction, and thus result in fusion only at the local segment or segments involved in the injury, depending on its severity and extent. (Kakulas and Bedbrook, 1976; Nicholl, 1949; Hughes, 1966). Pathological features of fractures and fracture-dislocations of the spine can be thus summarised:

1. Always three dimensional.

2. Always ragged.

3. After conservative reduction of the fracture-dislocation no further compression exists, or is very rare.

4. Extra-dural changes are common.

5. There is continuing neural change by hormonal and chemical factors.

6. They are not similar to experimental lesions.

7. Surgical procedures may cause aggravation.

8. Conservative bony stability occurs in 90 per cent of cases.

Thus the broad spectrum of the morbid anatomy and morbid physiology must be stressed.

\section{Neurological facts}

Sparing of neurological function must be meticulously noted. Primary pathological and neurological reasons to consider technical surgery vary with time and state, and include:

1. Late onset paresis due to a space occupying lesion, or

2. Gross vertebral displacement not responding to postural methods. 
3. Deterioration of neurology by a remedial cause.

4. A plateau caused by a remedial lesion such as stenosis.

But we must remember that there are secondary and tertiary factors which can cause deterioration and are thus contra-indications:

1. Infection, whether this be respiratory or urinary.

2. Bedsores.

3. Anoxia and hypotension.

4. Poor technical surgery by sporadic surgeons.

5. The wrong time, the wrong place, and the wrong surgeon.

Regretfully, early operative interference:

a. Has not resulted in better neurological improvement.

b. Has not been proved to be of great value in early mobilisation if bed mobilisation is practised.

c. Has resulted in increased morbidity and mortality.

d. Has resulted in stiff, immobile spines.

e. Denervates the erector spinae.

f. Does not reduce the effects of pathology, whether that be bony or neurological.

\section{Compensatory mechanisms}

Compensatory physiological mechanisms must be understood and studied in any surgical or rehabilitative therapy, and these include in the spinal injuries:

1. Muscles that bridge the spinal lesion, such as the trapezius.

2. Neurological bridges such as the sympathetic chain.

3. Extra-ordinary psychological and neurological compensations which occur regularly over a long period of time.

\section{Comprehensive units}

This is probably the most important academic principle in the management of paraplegia and tetraplegia due to spinal injury. The principle of early admission to properly organised spinal units must at all times be remembered. The rights of paraplegics must be respected. I do not believe in this decade that it is satisfactory for patients now to be ideally admitted primarily to neurosurgical, orthopaedic, or urological units. No other single factor has influenced the care and improved the natural history of spinal injuries as early admission to comprehensive units. Here in Europe 30 years ago such comprehensive units were established. Many authors, European, American, Japanese, Australian and British have shown how important this is for other injuries such as cranial and orthopaedic lesions as well as in paralytic spinal injury (Guttmann, 1973; Botterell et al., 1977; Botterell, 1978; Watson Jones, 1943; Dollfus, 1978).

I am reminded that the great Robert Jones in 1921 showed a similar improvement in recovery when non-spinal injuries, such as fractures of the femur and peripheral nerve injuries, were admitted to comprehensive units. Yet I regret to say that this major, well proven advance is still (after some four decades), 
not implemented early in many areas throughout the world, particularly perhaps in the American continent by those who advocate radical surgery (Yosipovitch et al., 1977; Flesch et al., 1977; Dickson et al., 1978). Young and Dexter's (1978) report emphasised how important comprehensive care is and how urgent it is for patients to be given such care. I believe in comprehensive care units where orthopaedic surgeon, neurosurgeon, and urologist meet and agree on methods. Only then can the problem of a particular method be put into perspective without bias and without prejudice.

Part-time care of any patient for short periods of time is poor care. The commonly experienced transition through one neurological or orthopaedic unit before admission to a comprehensive unit must be severely criticised if standards are to be improved. The real argument therefore is not whether one method is better than another, and whether that method is better than another in certain circumstances, but when sicuuld a method be advised. There is no argument that early operative care has an important but a small indication; and then as such it becomes the conservative method. The choice of certain technical methods compared with conservative care is the real question to be answered, not only by the surgeon but by the premier doctor looking after the patient. The argument can be answered only by providing the highest possible standards in all methods that are used in comprehensive units. How such goals can be reached, I believe, is not by governments or instrumentalities but by those of us involved in this subject, who have in mind the academic facts, whether we be orthopaedists, neurological, general or urological surgeons, or rehabilitation medicine consultants; for we must combine in a comprehensive discipline until such is achieved. Any measures, such as I am now advocating, can be regarded only as stepping stones in the advancement of good patient care based on the facts of academic importance, proven conclusively by their beneficial effect in care programmes.

\section{The academic problem of complications}

The importance of complications cannot be overstressed, particularly those neurological complications and deterioration caused by our therapeutic methods. Urological complications, for example, are still universal; detrusor and sphincter dyssynergia occur universally, even if infection no longer exists. In many areas infection is still a present and almost universal complication.

The eradication of infection, both by the work from Stoke Mandeville of Guttmann and Frankel (1966), and later by Pearman and England in 1976, are well known and I do not propose to discuss them except to indicate that Pearman's and England's reports show that 50 per cent of cases remain infection free, 40 per cent have irregular bacteriuria, and 10 per cent have heavy infection. These are similar to the results that we are able to achieve currently in Western Australia. Comprehensive units will be the only places in which severe infections can be prevented and indeed reduced. On reviewing the literature one came to the conclusion that early surgery was advocated despite the presence of decubiti and infection, which still seem to be accepted as inevitable. Let us not ignore, however, the other tertiary complications.

Young's (1981) figures indicated that the incidence of decubiti in the United States of America and in initial and long term care is 30 per cent. Our figures, 
in Western Australia is nil, and only one or two per cent in our total series.

Time does not permit me to talk about deep vein thrombosis, which has an incidence of 12 to 20 per cent, even in spinal injury units; but let me say that the prevention of neurological complications is a subject to which I gave some attention in my 1980 Stirling Lectures in Adelaide. Complications differ but I have records where 25 out of 40 patients operated on had complications, whilst in others indeed even up to 26 out of 95 . The recent International Year of and for Disabled People has emphasised all over the world the importance of prevention but unless complications are thoroughly and carefully considered on an academic basis then surgery may be undertaken under conditions which are not ideal. Thus these five well known basic and fundamental facts of pathology, neurology, compensatory mechanisms, comprehensive units and complications, must be considered and should be remembered as we discuss these matters in the next 2 or 3 days.

The proper place of open surgery can be best illustrated by Table 1 .

Table 1 Surgical reduction of spinal injuries with paraplegia

\begin{tabular}{|c|c|c|}
\hline Time & Indications & Contraindications \\
\hline $\begin{array}{r}1 \text { day } \\
\downarrow\end{array}$ & Gross irreducible injuries & \\
\hline 7 days & $\begin{array}{l}\text { Neurological deterioration with or without lucid period } \\
\text { plus spinal block } \\
\text { Gunshot wounds (some) } \\
\text { Rarely an indication for fixation in Comprehensive Unit }\end{array}$ & $\begin{array}{l}\text { Urinary tract infection } \\
\text { Septicaemia } \\
\text { Multiple injuries }\end{array}$ \\
\hline 6 week $\underset{\downarrow \text { weeks }}{\downarrow}$ & Incomplete lesions intolerent of conservative methods & $\begin{array}{l}\text { Acute gastric ulcer } \\
\text { Chest problems }\end{array}$ \\
\hline 6 weeks & $\begin{array}{l}\text { True late instability ( } 5 \text { per cent in cervico-dorsal, } 1 \text { per cent } \\
\text { lumbo-dorsal injuries) }\end{array}$ & Major social disease \\
\hline 3 months & $\begin{array}{l}\text { Progressive deformity } \\
\text { Non-union } \\
\text { Growth problems in children } \\
\text { Stenosis causing CNS plateauing }\end{array}$ & Decubiti \\
\hline 3 months & Disc pain & \\
\hline 12 months & Late non-union & \\
\hline
\end{tabular}

On considering these academic factors there is therefore a proper plan of treatment which will include:

1. Diagnosis in terms of:

(a) The maximum injury vector (White and Panjabi, 1978).

(b) Pathology: bony, disc, and neural.

(c) The time.

2. Treat all cases by posture while definitive decisions are considered.

3. Re-examine after one to two hours.

4. If reduced, posture, early physical rehabilitation, chest and isometric exercises, and then an exoskeleton is probably indicated.

5. If it is still unreduced, consider manipulation and then go back to posture. 
6. If it is still unreduced, then consider open surgery but remember the contraindications.

Having finally reduced the fracture, if that is necessary, then consider the postoperative management of prevention of complications, and remember as a complication re-displacement of the fracture. Conservative techniques may include:

1. First Aid.

2. The disciplined use of posture.

3. Technical procedures of many types.

4. The use of exoskeletons and preventive physical techniques.

5. Special operative techniques.

Table 2a illustrates methods available whilst Table $2 \mathrm{~b}$ shows early and late reasons for surgery.

Table 2a Management of spinal injuries with paraplegia

\begin{tabular}{|c|c|c|}
\hline \multicolumn{3}{|c|}{ Methods available have indications and/or contradictions } \\
\hline Method & Indications & Contradictions \\
\hline $\begin{array}{l}\text { Posture } \\
\text { Manipulation }\end{array}$ & $\begin{array}{l}\text { Universal } \\
\text { Failure to reduce posturally, } \\
\text { e.g. flexion rotation }\end{array}$ & $\begin{array}{l}\text { None } \\
\text { Multiple injuries } \\
\text { Wrong place } \\
\text { Wrong surgeon }\end{array}$ \\
\hline Traction & In many cervical injuries & Stable injuries \\
\hline Exoskeletons & $\begin{array}{l}\text { Can be used in many cases after } \\
\text { initial care }\end{array}$ & $\begin{array}{l}\text { Ileus } \\
\text { Elderly } \\
\text { Sensory paralysis }\end{array}$ \\
\hline $\begin{array}{l}\text { Open reduction \& } \\
\text { fixation }\end{array}$ & $\begin{array}{l}\text { Gross dislocation } \\
\text { Specific } \\
\text { Feural deterioration } \\
\text { Failure of posture } \\
\text { True late instability }\end{array}$ & $\begin{array}{l}\text { Specific infection } \\
\text { U.T.I. } \\
\text { Other injuries }\end{array}$ \\
\hline $\begin{array}{l}\text { Anterior } \\
\text { Decompression }\end{array}$ & Specific- $_{\text {plateauing }}$ & Specific-U.T.I. \\
\hline $\begin{array}{l}\text { Motor \& sensory } \\
\text { Restoration }\end{array}$ & Universal & None \\
\hline
\end{tabular}

Table 2b Use of technical procedures

\begin{tabular}{|c|c|c|}
\hline & Indications & Contraindications \\
\hline Early & $\left\{\begin{array}{l}\text { Progressive Neurology } \\
\text { Lucid Period } \\
\text { Gunshot } \\
\text { Failure to reduce }\end{array}\right.$ & $\begin{array}{l}\text { U.T.I } \\
\text { Pressure } \\
\text { Septicaemia } \\
\text { Skin problems } \\
\text { Multiple Injuries }\end{array}$ \\
\hline Late & $\left\{\begin{array}{l}\text { Non-union } \\
\text { Deformity } \\
\text { Plateauing }\end{array}\right.$ & $\begin{array}{l}\text { Acute Peptic Ulcer } \\
\text { Chest complications }\end{array}$ \\
\hline
\end{tabular}

\section{The real argument}

The fundamental debate thus falls around a particular group of fractures i.e. the flexion rotation fracture-dislocation of the cervical and lumbo-dorsal spine 
and I must remind you of a few difficulties that occur. Pathologically, continuing compression after postural reduction has been proved not to occur but occasionally compression may develop in the later stages with stenosis.

What of the patients in this debate about management? They are generally passive, but occasionally not so, and in the later stages of management careful discussion will certainly help. In the early stages, only rarely can such discussion be undertaken because of the severity of the condition. As medical scientists we pride ourselves on facts, yet they are not always reliable. Patients themselves, for example, have taught me a great deal:

A female aged 22 with a fracture-dislocation at T.12.L.1-a gross fracturedislocation that I could not reduce posturally was offered operative reduction. She accepted on the condition that no blood was to be used. As this was impossible, she asked if manipulative care could be undertaken. This was undertaken with complete success and there was neurological recovery.

Each method, therefore, has its proper place in time, indications and contraindications (Table 1). The progressive care needed I have already enunciated. I would remind you that in 1921 the late Sir Robert Jones said of the then emergent orthopaedic surgeon: 'Function is his goal. He should know and be able to practise the best way of obtaining such function. The operation means only the beginning of his problem, and his most brilliant operative exploit, unless directed to a functional success, should be considered to be a reproach.' So it is in spinal injuries, paralytic and non-paralytic, that function as a whole in each patient is the goal. The balance of management is important-a balance at all times between an indication for a particular method and a contra-indication for that procedure. A total care programme between hospital and community is essential. I have been honoured to briefly address you today, and look forward in a spirit of friendship to the important discussions of the next two days.

\section{References}

BEDBROOK GM 1980 (a) The reduction of orthopaedic disability by rehabilitative methods.

(b) Prevention of complications in the severely disabled. The Stirling Lectures, delivered to the South Australian Postgraduate Medical Association, Adelaide. (Published as a monograph; 1981, by Aust. Council for Rehabilitation of The Disabled).

Botterell EH 1978 Acute cord injury. Parts 1 \& 2. Journal of the Royal College of Surgeons (Edin) 23:57-64, 107-116.

Botterell EH, Jousse AI, Kraus AS, Thompson MG, Wynne-Jones M \& Geisler WO 1977 A model for the future care of acute spinal cord injuries. Canadian Journal of Neurological Sciences 2:361-380.

DiCKSON JH, HARRINGTON RP, ERWIN WD 1978 Results of reduction and stabilization of the severely fractured thoracic and lumbar spine. Journal of Bone and Joint Surgery 60-A:799-805.

Dollfus P 1978 Note on the spinal fractures with paraplegia treated by the Boehler's plaster of Fontainebleau. (Personal communication).

Flesh JR, LeIDER LL, ERIKSON DL, ChOU SN, BRADFord DS 1977 Harrington instrumentation and spine fusion for unstable fractures and fracture-dislocations of the thoracic and lumbar spine. Journal of Bone and Joint Surgery 59-A:143-153.

GutTMANN L 1973 Spinal cord injuries. Comprehensive management and research. Blackwell Scientific Publications, Oxford.

Guttmann L, Frankel H 1966 The value of intermittent catheterisation in the early management of traumatic paraplegia and tetraplegia. Paraplegia 4:63-83.

Hughes JT 1966 Pathology of spinal cord. Lloyd Luke Medical Books Pty Ltd, London.

JONES R 1921 Orthopaedic surgery of injuries. Vol. 2. Oxford Medical Publishers, London.

Kakulas BA, BedBrook GM 1976 Pathology of injuries of the vertebral column. In: PJ 
Vinken and GW Bruyn (Eds), Handbook of Clinical Neurology 25:27-42, North Holland Publishing Co., Amsterdam.

Keith A 1919 Menders of the Maimed. Oxford Medical Publishers, London.

NiCOLL EA 1949 Journal of Bone and Joint Surgery 31-B:376.

Pearman JW, England EJ 1973 The urological management of the patient following spinal cord injury. Charled C. Thomas, Springfield, Illinois.

Leach RE, Hoaglund FT, Riseborough EJ et al. 1982 Controversies in Orthopaedic Surgery. W. B. Saunders Company, Philadelphia, U.S.A.

Pearman JW, England EJ 1976 The urinary tract. In: P. J. Vinken and G. S. Bruyn (Eds). Handbook of Clinical Neurology 26:409-436. North Holland Publishing Co., Amsterdam.

Watson-Jones R 1943 Fractures and Joint Injuries. Vol. I, 3rd edition, 314-318. Churchill Livingstone, Edinburgh.

White AA, Panjabi MM 1978 Clinical biomechanics of the spine. J. B. Lippincott Co., Philadelphia.

Yosipovitch Z, Robin GC, Makin M 1977 Open reduction of unstable thoracolumbar spinal injuries and fixation with Harrington rods. Journal of Bone and Joint Surgery 59-A:1003-1015.

YOUNG JS, DEXTER WR 1978 Neurological recovery distal to the zone of injury in 172 cases of closed traumatic spinal cord injury. Paraplegia 16:39-49.

Young JS, BuRns PE 1981 Pressure Sores and the Spinal Injured. Part I: S.C.I. Digest 3: No. 3, Page 9, Fall (1981). Part II: S.C.I. Digest, 3, No. 4, Page 11, Winter (1981). 